\title{
Effect of Microbial Consortia as Basal Application and Foliar Spray of Gluconacetobacter diazotropicus on Growth, Yield and Nutrient Uptake by Maize
}

\author{
Garima Padwar ${ }^{1 *}$, N. G. Mitra1, Tikam Chand Yadav', \\ R. K. Sahu ${ }^{1}$ and Gaurav Padwar ${ }^{2}$ \\ ${ }^{1}$ Department of soil science and Agricultural Chemistry, Jawaharlal Nehru Krishi Vishwa \\ Vidhyalaya, Jabalpur, Madhya Pradesh-482004, India \\ ${ }^{2}$ Department of forestry wildlife and environmental science Guru Ghasidas University, \\ Bilashpur, Chhattisgarh-495009, India \\ *Corresponding author
}

\section{A B S T R A C T}

\section{Keywords}

Maize,

G. diazotrophicus, Arthrobacter, PSB, KSB, Yeild, FUI

\section{Article Info}

Accepted:

20 May 2020

Available Online:

10 June 2020
The experiment on Effect of microbial consortia as basal application and foliar spray of G. diazotropicus on maize (Zea maize) was carried out during Kharif 2018 in the experimental field under Department of Soil Science \& Agricultural Chemistry. The experiment was laid out under randomized block design (RBD) with 3 replications having 18 treatments of microbial consortia of Arthrobacter sp., phosphate solubilizing bacteria (Bacillus sp.) and potash solubilizing bacteria (Fraturia aurentia) as seed treatment and additionally, Gluconacetobacter diazotrophicus was applied as foliar application at 25, 45 and 65 DAS of the crop growth stages. The crop was supplemented with recommended dose of fertilizers 120:60:40 $\left(\mathrm{N}: \mathrm{P}_{2} \mathrm{O}_{5}: \mathrm{K}_{2} \mathrm{O} \mathrm{kg} / \mathrm{ha}\right)$ at basal application. Besides these, two types of control plots were maintined as fertilized uninoculated control (FUI) and unfertilized uninoculated control (UFUI Regarding findings towards study of growth, yield and nutrient uptake by maize, the treatment combinations of $\mathrm{F}+G$. diazotropicus + Arthro $+\mathrm{PSB}+\mathrm{KSB}$ increased plant height by 75.5, 42.8 and $26.7 \%$, plant biomass (fresh and dry) by $87.3,26.3$ and $36.6 \%$, and $8.72,41.9$ and $28.1 \%$, respectively and leaf chlorophyll content by 49.6, 48.5 and $16.6 \%$ at 35,55 and 75 DAS. The same treat combination yielded maximum grain and stover at harvest by 33.4 and $77.9 \%$, respectively over the control $\left(2146\right.$ and $\left.6029 \mathrm{~kg} \mathrm{ha}^{-1}\right)$ with major nutrient contents by $17.5,14.7$ and $18.9 \%$ more in $\mathrm{N}, \mathrm{P}$ and $\mathrm{K}$, respectively. These were all the positive influence of $G$. diazotropicus and Arthrobacter when crop was supplemented with sufficient available nutrient particularly phosphorus with PSB, as the soil was moderately deficient of phosphorus. However, response of KSB was not evident since the soil was sufficient with potash.

\section{Introduction}

Maize (Zea mays L.) is the most widely distributed cereal crop of the world. India occupies fifth place in acreage and ranks $10^{\text {th }}$ in production and is the third after wheat and rice in total food grain production. In our country, more than $50 \%$ of maize produce is being used as animal feed. The state of Madhya Pradesh occupies 13\% of the total maize area and contributing equally to the total maize production in the country. Nutritionally, maize contains 60 to $68 \%$ starch, 1.2 to $5.7 \%$ edible oil and 7 to $15 \%$ protein. In India, maize is grown in an area of 7.18 million hectares contributing 14.1 
million tonnes of production with a productivity of $1959 \mathrm{~kg} \mathrm{ha}^{-1}$ (Agriculture Statistics at a glance, 2016).

Gluconacetobacter diazotrophicus is a gramnegative, flagellated bacilli, darkish brown or orange colonies under a microscope, aerobic, obligate endophytic (an endosymbiont), and nitrogen-fixing endophytes in nonleguminous plants, (Sevilla et al., 2001). Nitrogen fixing bacterium originally found in monocotyledon sugarcane plants in which the bacterium actively fixes atmosphere $\mathrm{N}$ and provides significant amounts of $\mathrm{N}$ to plants. Ever since it was first isolated from the phyllosphere as well as the rhizosphere of inter-cellular spaces of sugarcane. It may actually fix up to $70 \%$ of their $\mathrm{N}$ requirements. Using seedlings grown aseptically in sucrose-containing culture media, it has been shown that inoculation with very low numbers of $G$. diazotrophicus results in extensive intracellular colonization of roots and progressive systemic intracellular root colonization, enabling non-nodular endosymbiotic $\mathrm{N}$ fixation from the atmosphere. Amazingly, the bacterium is capable of affecting a very wide range of plants.

Additionally, it possesses many other characteristics potentially valuable in the area of agriculture viz., plant growth promotion, sugar metabolism pathways, secretion of organic acids, promotes an increase in the solubility of phosphate as well as zinc (Saravanan et al., 2007), synthesis of auxin, antifungal-antibacterial properties and the occurrence of bacteriocins (proteinaceous toxins inhibiting the growth of closely related bacterial strains). The bacterium is less plant/crop specific and found in a number of unrelated plant species. G. diazotrophicus requires a large amount of sucrose for adequate growth (Dong et al., 1994). It was being recommended as a biofertilizer for sugar crops. G. diazotrophicus has potentials to fix atmospheric nitrogen up to $300 \mathrm{~kg} \mathrm{ha}^{-1}$. In addition to fixing $\mathrm{N}_{2}$, it has the ability to produce significant amounts of plant growth hormones like IAA (Indole Acetic Acid) and gibberellins in culture ( Bastian et al., 1999).

Phosphate solubilizing bacteria (PSB) have attracted the attention of agriculturists as soil inoculums to improve the plant growth and yield. Phosphorus besides directly providing vital energy package to plant system, also creates for a balanced nutrient utilization and absorption by all living system including diazotrophic microbes and PGPR. Simple inoculation of seeds with PSB gives crop yield responses equivalent to $30 \mathrm{~kg} \mathrm{P}_{2} \mathrm{O}_{5} / \mathrm{ha}$ or 50 percent of the need for phosphatic fertilizers. Many different species of bacteria have been identified as PSB like Bacillus phosphaticus, B. megatherium, Pseudomonas putida. PSB are beneficial bacteria capable of solubilizing inorganic phosphorus from insoluble compounds. P-solubilization ability of rhizosphere microorganisms is considered to be one of the most important traits associated with plant phosphate nutrition. It is generally accepted that the mechanism of mineral phosphate solubilization by PSB strains is associated with the release of low molecular weight organic acids, through which their hydroxyl and carboxyl groups chelate the cations bound to phosphate, thereby converting it into soluble forms. PSB have been introduced to the Agricultural community as phosphate biofertilizer.

After nitrogen (N) and phosphorus (P), potassium $(\mathrm{K})$ is the most important plant nutrient that has a key role in the growth, metabolism and development of plants. In addition to increasing plant resistance to diseases, pests, and abiotic stresses. Depending on soil type, from 90 to $98 \%$ of soil $\mathrm{K}$ is mineral $\mathrm{K}$ and most of this $\mathrm{K}$ is unavailable for plant uptake (Sparks and 
Huang, 1985). It was reported that some beneficial soil microorganisms, a wide range of saprophytic bacteria including Farteuria aurentia, fungal strains and actinomycetes, could solubilize the insoluble $\mathrm{K}$ to soluble forms of $\mathrm{K}$ by various mechanisms including "(i) by lowering the $\mathrm{pH}$; (ii) by enhancing chelation of the cations bound to $\mathrm{K}$; and (iii) acidolysis of the surrounding area of microorganism". Frateuria aurantia is a species of Proteobacteria. The cells are mostly straight rods.

Co-inoculation of the beneficial microorganisms improves growth attributes, yields of maize and nutrient status in plant (Awasthi et al., 2011).

\section{Materials and Methods}

The experiment was carried out during Kharif at the Research field Department of Soil Science and Agricultural Chemistry, JNKVV, Jabalpur. The recommended dose of fertilizer 120:60:40 ( $\left.\mathrm{N}: \mathrm{P}_{2} \mathrm{O}_{5}: \mathrm{K}_{2} \mathrm{O} \mathrm{kg} / \mathrm{ha}\right)$ for maize crop was applied in the form of urea, single super phosphate (SSP) and murate of potash (MOP) as basal applications to each plot as per recommendation.

Seed treatment (basal application) of microbial consortium containing Potash solubilizing bacteria- Fraturia aurentia, phosphate solubilizing bacteria (Bacillus sp.) and Arthrobacter sp. In addition, Gluconacetobacter diazotrophicus was applied as foliar application at 25, 45 and 65 DAS of the crop growth stages.

\section{Plant height}

Plant height was measured at 35, 55 and 75 DAS. Three plants from each plot were taken under observation and their heights were measured.

\section{Total chlorophyll content}

The total chlorophyll content was estimated following the method of Arnon (1949) and expressed as $\mathrm{mg} \mathrm{g}^{-1}$ fresh weight.

\section{Plant biomass}

\section{Plant fresh weight}

At 45 DAS, the root portion of three plants was cut off and fresh plant biomass was recorded in g plant $^{-1}$.

\section{Plant dry biomass}

After recording the fresh plant biomass, plants were dried in hot air oven at $60^{\circ} \mathrm{C}$ for $3-4$ days (till constant weight) to record the dried plant biomass in $\mathrm{g}_{\text {plant }}{ }^{-1}$.

\section{Germination percentage}

Germination percentage of seed was recorded at $4^{\text {th }}$ and $6^{\text {th }}$ days after sowing with help of formula.

$$
\text { Germination \% }=\frac{\text { Number of seed germinated }}{\text { Number of seed sown }} \times 100
$$

\section{Digestion of plant samples}

The plants samples were subjected to wet digestion for estimation of various nutrients in grain and straw Mixture of $\mathrm{HNO} 3$ and $\mathrm{HClO} 4$ was added in 2.5:1 ratio (v/v) for estimation of major nutrients.

\section{Total nitrogen}

The nitrogen content of soybean plant was estimated on dry weight basis by microkjeldahl method as per procedure suggested by AOAC (1995). 


\section{Total phosphorus and potassium}

The phosphorus contents in grain and straw of soybean were estimated on dry weight basis by vanado-molybdate yellow colour method as suggested by Bhargava and Raghupathi (1984). The potassium content in the digested material was directly estimated. Nutrients uptake by soybean was calculated in kg ha-1 in relation to dry with a flame photometer using the procedure of Bhargava and Raghupathi (1984).matter production by using the following formula.

Nutrient uptake (kg ha-1) $=\frac{\text { Content }(\%) \text { x yield }(\mathrm{kg} \mathrm{ha}-1)}{100}$

\section{Results and Discussion}

\section{Plant height}

Table 1 presents data on plant height at 35, 55 and 75 DAS of the crop. The data on plant height at 35 DAS varied from 39.2 to $19.9 \mathrm{~cm}$ plant $^{-1}$. Among all the treatments, the treatment combination of $\mathrm{F}+G$. diazotropicus + Arthro $+\mathrm{PSB}+\mathrm{KSB}$ increased the plant height at the maximum by $75.7 \%$, followed by, $\mathrm{F}+G$. diazotropicus + Arthro $+\mathrm{PSB}, \mathrm{F}+$ Arthro $+\mathrm{PSB}+\mathrm{KSB}, \quad \mathrm{F}+$ G. diazotropicus + Arthro+KSB with 68.1, 58.7 and $56.1 \%$ response, respectively over the control (22.3 cm plant $\left.^{-1}\right)$.

The data on plant height at 55 DAS ranged from 90.7 to $57.1 \mathrm{~cm} \mathrm{plant}^{-1}$. ). Among all the treatments, the treatment combination of $\mathrm{F}+G$. diazotropicus + Arthro $+\mathrm{PSB}+\mathrm{KSB}$ performed the best by $42.8 \%$, followed by $\mathrm{F}+G$. diazotropicus + Arthro $+\mathrm{PSB}, \quad \mathrm{F}+$ Arthro+ $\mathrm{PSB}+\mathrm{KSB}$ and $\mathrm{F}+$ G. diazotropicus + Arthro+ KSB with $35.9,32.3$ and $21.4 \%$ response, respectively over the control $(63.3 \mathrm{~cm}$ plant $\left.{ }^{1}\right)$. The data on plant height 75 DAS varied from 217 to $168 \mathrm{~cm}$ plant $^{-1}$. the treatment combination of $\mathrm{F}+G$. diazotropicus + Arthro $+\mathrm{PSB}+\mathrm{KSB}$ responded the best by $12.4 \%$, followed by $\mathrm{F}+G$. diazotropicus + Arthro, $\mathrm{F}+$ G. diazotropicus + Arthro $+\mathrm{PSB}$ and $\mathrm{F}+G$. diazotropicus $+\mathrm{KSB}$ by $9.32, \quad 8.88$ and $7.25 \%$ response, respectively over the control $\left(193 \mathrm{~cm}\right.$ plant $\left.{ }^{-1}\right)$ Similarly, studied that the effectiveness of inoculation of Acetobacter diazotrophicus to corn plant was beneficial in growth of plant. Triplett (1996).

\section{Plant biomass (fresh and dry)}

Table 2 represents the data on biomass (fresh and dry) production of maize plants at 35,55 and 75 DAS. The fresh weight at 35 DAS ranged from 19.67 to $9.07 \mathrm{~g}$ plant $^{-1}$. Among all the treatments, $\mathrm{F}+G$. diazotropicus + Arthro+PSB+KSB responded the best followed by $\mathrm{F}+G$. diazotropicus + Arthro+ $\mathrm{PSB}, \mathrm{F}+$ Arthro $+\mathrm{PSB}+\mathrm{KSB}$ and $\mathrm{F}+G$. diazotropicus + Arthro $+K S B$ respectively over FUI (10.5 g plant $\left.^{-1}\right)$.

The fresh weight at 55 DAS ranged from 177 to $89.0 \mathrm{~g} \mathrm{plant}^{-1}$. Among all the treatments, $\mathrm{F}+G$ diazotropicus + Arthro $+\mathrm{PSB}+\mathrm{KSB}$ responded the best by $25.8 \%$ followed by $\mathrm{F}+G$. diazotropicus + Arthro $+\mathrm{PSB}, \mathrm{F}+$ Arthro+ $\mathrm{PSB}+\mathrm{KSB}$ and $\mathrm{F}+G$. diazotropicus + Arthro $+K S B$ by $25.4,23.6$, and $20.4 \%$ respectively over FUI (93.0 g plant $\left.{ }^{-1}\right)$.

The fresh weight at 75 DAS ranged from 147 to $107 \mathrm{~g} \mathrm{plant}^{-1}$. Among all the treatments, $\mathrm{F}+G$. diazotropicus + Arthro $+\mathrm{PSB}+\mathrm{KSB}$ responded the best by $28.9 \%$ followed by $\mathrm{F}+$ $G$. diazotropicus + Arthro+PSB, $\mathrm{F}+G$. diazotropicus + Arthro and $\mathrm{F}+G$. diazotropicus + PSB by 26.3, 26.1 and $24.5 \%$ respectively over FUI (114 $\mathrm{g} \mathrm{plant}^{-1}$ ). The data on dry weight at 35 DAS varied from 3.53 to $13.8 \mathrm{~g}$ plant $^{-1}$ leaf. Among all the treatments, $\mathrm{F}+G$. diazotropicus + Arthro $+\mathrm{PSB}+\mathrm{KSB}$ responded the best followed by $\mathrm{F}+G$. diazotropicus 
$+\mathrm{PSB}+\mathrm{KSB}, \mathrm{F}+$ Arthro+ $\mathrm{PSB}+\mathrm{KSB}, \mathrm{F}+G$. diazotropicus + Arthro+ $\mathrm{PSB}$, respectively over FUI (4.47 $\mathrm{g}$ plant $\left.^{-1}\right)$. The data on dry weight at 55 DAS varied from 63.6 to $41.1 \mathrm{~g}$ plant ${ }^{-1}$ leaf. Among all the treatments, $\mathrm{F}+G$. diazotropicus + Arthro $+\mathrm{PSB}+\mathrm{KSB}$ responded the best by $41.9 \%$ followed by $\mathrm{F}+$ Arthro $+\mathrm{PSB}, \mathrm{F}+$ G. diazotropicus + Arthro+ $\mathrm{KSB}$ and $\mathrm{F}+G$. diazotropicus + Arthro $+\mathrm{PSB}$ by $34.1,29.6$ and $29.0 \%$ respectively over FUI (44.8 g plant $\left.^{-1}\right)$.

The data on dry weight at 75 DAS varied from 95.2 to $72.2 \mathrm{~g}$ plant $^{-1}$ leaf. Among all the treatments, $\mathrm{F}+G$. diazotropicus + Arthro+ $\mathrm{PSB}+\mathrm{KSB}$ responded the best by $28.1 \%$ followed by $\mathrm{F}+$ Arthro $+\mathrm{PSB}+\mathrm{KSB}, \mathrm{F}+G$. diazotropicus $+\mathrm{PSB}+\mathrm{KSB}, \quad \mathrm{F}+G$. diazotropicus + Arthro $+\mathrm{PSB}$ by $24.8,17.6$ and $17.3 \%$ respectively over FUI (74.3 g plant $\left.^{-1}\right)$.

Jambukar (2003) also confirmed the finding that among the different treatments tested, the treatment $\mathrm{T}_{8}$ (Azotobacter+Acetobacter $+75 \%$ $\mathrm{N})$ showed significant improvement in fresh weight, dry weight, number of leaves per plant of beet root. Linu (2009) reported that seed inoculation of cowpea by phosphate solublizers improved nodulation, root and shoot biomass, straw and grain yield and phosphorous and nitrogen uptake of crop.

\section{Chlorophyll content}

Table 3 exhibits the data on total chlorophyll content in leaf at 35, 55 and 75 DAS. The data on chlorophyll content at 35 DAS varied from 1.96 to $1.01 \mathrm{mg} \mathrm{g}^{-1}$ leaf. The treatment combination of $\mathrm{F}+G$. diazotropicus + Arthro+PSB+KSB , among all the treatments, increased leaf chlorophyll content by $49.6 \%$, followed by $\mathrm{F}+G$. diazotropicus $+\mathrm{PSB}+\mathrm{KSB}$, $\mathrm{F}+$ Arthro $+\mathrm{PSB}+\mathrm{KSB}$ and $\mathrm{F}+G$. diazotropicus + Arthro+PSB by 43.5, 37.4 and $37.3 \%$, respectively over the control $\left(1.34 \mathrm{mg} \mathrm{g}^{-1}\right.$ leaf). The data on chlorophyll content at 55 DAS varied from 1.99 to $1.19 \mathrm{mg} \mathrm{g}^{-1}$ leaf with the mean value of $1.60 \mathrm{mg} \mathrm{g}^{-1}$ leaf. The treatment combination of $\mathrm{F}+G$. diazotropicus +Arthro+PSB+KSB, among all the treatments, increased leaf chlorophyll content by $48.5 \%$, followed by $\mathrm{F}+$ Arthro+ $\mathrm{PSB}+\mathrm{KSB}, \mathrm{F}+$ G.diazotropicus + Arthro $+\mathrm{PSB}$ and $\mathrm{F}+G$. diazotropicus $+\mathrm{KSB}+\mathrm{PSB}$ by 42.5 , 38.0 and $54.6 \%$, respectively over the control (1.19mg g ${ }^{-1}$ leaf).

The data on chlorophyll content at 75 DAS varied from 1.90 to $1.27 \mathrm{mg} \mathrm{g}^{-1}$ leaf with the mean value of $1.64 \mathrm{mg} \mathrm{g}^{-1}$ leaf. The treatment combination of $\mathrm{F}+G$. diazotropicus + Arthro+PSB+KSB, among all the treatments, increased leaf chlorophyll content by $16.5 \%$, followed by $\mathrm{F}+$ Arthro $+\mathrm{PSB}+\mathrm{KSB}, \mathrm{F}+$ G.diazotropicus + Arthro $+\mathrm{PSB}$ and $\mathrm{F}+$ G.diazotropicus+KSB +PSB by 14.7, 9.20 and $8.58 \%$, respectively over the control (1.6mg g ${ }^{-1}$ leaf). Madhaiyan et al., (2004). also observed higher photosynthetic activity by enhancing the number of stomata, chlorophyll concentration and maleic acid content of crops.

\section{Germination percent}

Table 4 presents data on germination percent at $4^{\text {th }}$ and $6^{\text {th }}$ DAS after sowing of the crop. The data on plant height at $4^{\text {th }}$ DAS varied from 53.7 to $39.0 \%$. Among all the treatments, the treatment combination of $\mathrm{F}+$ Arthro+KSB, increase the Germination \% at the maximum by $19.3 \%$, followed by $\mathrm{F}+\mathrm{PSB}+\mathrm{KSB}, \mathrm{F}+$ G. diazotropicus $+\mathrm{KSB}$ and $\mathrm{F}+G$. diazotropicus + Arthro $+\mathrm{PSB}+\mathrm{KSB}$ with $14.1,13.3$ and $13.0 \%$ response, respectively over the control $(45.0 \%)$. The data on plant height at $6^{\text {th }}$ DAS ranged from 72.7 to $56.3 \%$. Among all the treatments, the treatment combination of $\mathrm{F}+G$. diazotropicus + Arthro+ $\mathrm{PSB}+\mathrm{KSB}$ performed the best by $18.4 \%$, followed by $\mathrm{F}+G$. diazotropicus $+\mathrm{PSB}+\mathrm{KSB}$, 
$\mathrm{F}+$ Arthro $+\mathrm{PSB}+\mathrm{KSB}, \mathrm{F}+G$. diazotropicus + Arthro $+K S B$ and $\mathrm{F}+$ Arthro with 15.8, 15.1 and $12.5 \%$ response, respectively over the control ( $61.3 \%)$.

Similarly, studied that the response of sweet sorghum to A. diazotrophicus, Azospirillum brasilense, Azotobacter chroococcum, Glomus leptoticum and interaction of these diazotrophic bacteria with the VAM fungus in respect to plant growth parameters.In this experiment they recorded more per cent germination, seedling vigour index, all growth parameters (number of leaves, length of shoot and root, stem girth) and dry weight of shoot and root of sweet sorghum. Bhowmik and Konde (1999).

\section{NPK contents in plant}

Table 5 and 6 presents the data on contents of nitrogen, phosphorus and potassium in grain and stover. The data on nitrogen content in grain varied from 1.16 to $1.41 \% \mathrm{~N}$. Among all the treatment combinations, $\mathrm{F}+G$. diazotropicus + Arthro $+\mathrm{PSB}+\mathrm{KSB}$ responded the best by $21 \%$ increase, followed by $\mathrm{F}+$ Arthro $+\mathrm{PSB}+\mathrm{KSB}, \mathrm{F}+G$. diazotropicus + Arthro $+K S B$ and $\mathrm{F}+G$. diazotropicus + PSB+KSB by $20.6,19.8$ and $18.9 \%$ increase, respectively over the control $(1.16 \% \mathrm{~N})$.

The data on phosphorus content in grain varied from 0.32 to $0.39 \% \mathrm{P}$ with the mean value $0.35 \% \mathrm{P}$. Among all the treatment combinations, $\mathrm{F}+G . \quad$ diazotropicus+ Arthro+PSB+KSB responded the best by $21.8 \%$ increase, followed by, $\mathrm{F}+G$. diazotropicus + Arthro + KSB,$\quad \mathrm{F}+$ Arthro + $\mathrm{PSB}+\mathrm{KSB}$ and $\mathrm{F}+G$. diazotropicus $+\mathrm{PSB}+$ $\mathrm{KSB}$ by 18.7, 15.6 and $12.5 \%$ increase, respectively over the control $(0.32 \% \mathrm{P})$.

The data on potassium content in grain varied from 0.56 to $0.69 \% \mathrm{~K}$ with the mean value $0.62 \% \mathrm{~K}$. Among all the treatment combinations, $\mathrm{F}+G . \quad$ diazotropicus+
Arthro+PSB+KSB responded the best by $23.2 \%$ increase, followed by $\mathrm{F}+G$. diazotropicus $+\mathrm{PSB}+\mathrm{KSB}, \quad \mathrm{F}+G$. diazotropicus + Arthro $+K S B$ and $\mathrm{F}+G$. diazotropicus + Arthro+PSB by 21.4, 19.6 and $17.8 \%$ increase, respectively over the control $(0.56 \% \mathrm{~K})$.

The data on nitrogen content in stover varied from 0.90 to $1.05 \% \mathrm{~N}$. Among all the treatment combinations, $\mathrm{F}+G$. diazotropicus + Arthro $+\mathrm{PSB}+\mathrm{KSB}$ responded the best by $16 \%$ increase, followed by $\mathrm{F}+$ Arthro $+\mathrm{PSB}+$ $\mathrm{KSB}, \mathrm{F}+G$. diazotropicus + Arthro $+K S B$ and $\mathrm{F}+G$. diazotropicus $+\mathrm{PSB}+\mathrm{KSB}$ by $15.5,14.4$ and $13.3 \%$ increase, respectively over the control $(0.90 \% \mathrm{~N})$.

The data on phosphorus content in stover varied from 0.23 to $0.29 \% \mathrm{P}$. Among all the treatment combinations, $\mathrm{F}+G$. diazotropicus + Arthro $+\mathrm{PSB}+\mathrm{KSB}$ responded the best by $26.08 \%$ increase, followed by, $\mathrm{F}+G$. diazotropicus $+\mathrm{PSB}+\mathrm{KSB}, \quad \mathrm{F}+G$. diazotropicus + Arthro $+\mathrm{PSB}$ and $\mathrm{F}+$ Arthro $+\mathrm{PSB}+\mathrm{KSB}$ by 21.7, 17.3 and $17.0 \%$ increase, respectively over the control $(0.23 \% \mathrm{P})$. Similarly, potassium content in stover varied from 0.81 to $0.92 \% \mathrm{~K}$. Among all the treatment combinations, $\mathrm{F}+G$. diazotropicus + Arthro $+\mathrm{PSB}+\mathrm{KSB}$ responded the best by $15.00 \%$ increase, followed by $\mathrm{F}+G$. diazotropicus + Arthro+PSB, $\mathrm{F}+G$. diazotrophicus + Arthro $+\mathrm{KSB}$ and $\mathrm{F}+$ Arthro $+\mathrm{PSB}+\mathrm{KSB}$ by 12.3, 11.1 and $9.87 \%$ increase, respectively over the control $(0.81 \% \mathrm{~K})$ which has been supported by the findings of Vessey (2003) reported that the potential improving $\mathrm{K}$ and $\mathrm{P}$ nutrition by application of PGPR including phosphate and potash solubilizing bacteria (PSB and KSB) as biofertilizers as a sustainable solution to improve plant nutrient status and production.

\section{Grain and stover yields}

Table 6 and 7 exhibits the data on yields of 
grain and stover. The data on grain yield ranged from 1348 to $2863 \mathrm{~kg} \mathrm{ha}^{-1}$. Among all the treatment combinations, responded the best $\mathrm{F}+$ G. diazotropicus + Arthro $+\mathrm{PSB}+\mathrm{KSB}$ by $33.4 \%$, followed by the treatment combinations $\quad \mathrm{F}+G$. diazotropicus+ Arthro+PSB, $\quad \mathrm{F}+G$. diazotropicus + Arthro $+K S B$ and $\mathrm{F}+$ Arthro $+\mathrm{PSB}$, by 30.1 , 28.3 and $25.4 \%$, respectively over the control $\left(1348 \mathrm{~kg} \mathrm{ha}^{-1}\right)$ which has been supported by the findings of Jain et al., (1999) conducted field experiment to study the effect of PSB and biofertilizer Rhizobium on growth, yield attributes of chickpea in sandy loam soil. Inoculation of Rhizobium and PSB alone or in combination with 30,45 and $60 \mathrm{~kg} \mathrm{P}_{2} \mathrm{O}_{5}$ ha $^{-}$ ${ }^{1}$ markedly enhanced the seed yield, stover yield and protein content over its independent application of 'P'.

Table.1 Effect of microbial consortia as basal application and foliar spray of G. diazotropicus at different growth stages on plant height of maize

\begin{tabular}{|l|c|c|c|}
\hline \multirow{2}{*}{ Treatments } & \multicolumn{3}{c|}{ Plant height (cm plant } \\
\cline { 2 - 4 } & 35 DAS & 55 DAS & 75 DAS \\
\hline G. diazotropicus & 20.0 & 58.6 & 185 \\
\hline F+G. diazotropicus & 26.5 & 66.9 & 206 \\
\hline F+Arthro & 28.1 & 70.2 & 194 \\
\hline F+PSB & 25.1 & 69.7 & 210 \\
\hline F+KSB & 23.6 & 72.0 & 211 \\
\hline F+G. diazotropicus+Arthro & 31.1 & 73.2 & 202 \\
\hline F+G. diazotropicus + PSB & 29.3 & 73.8 & 196 \\
\hline F+G. diazotropicus+KSB & 27.6 & 68.0 & 210 \\
\hline F+ Arthro+ PSB & 32.7 & 72.7 & 204 \\
\hline F+Arthro+KSB & 25.5 & 65.0 & 207 \\
\hline F+PSB + KSB & 24.2 & 75.0 & 207 \\
\hline F+G. diazotropicus + Arthro + PSB & 37.5 & 86.3 & 210 \\
\hline F+G. diazotropicus + Arthro + KSB & 34.8 & 77.1 & 204 \\
\hline F+G. diazotropicus + PSB + KSB & 30.4 & 71.7 & 198 \\
\hline F+ Arthro + PSB + KSB & 35.4 & 84.0 & 205 \\
\hline F+G. diazotropicus + Arthro + PSB + & 39.2 & 90.7 & 217 \\
\hline KSB & & & \\
\hline FUI & 22.3 & 63.5 & 193 \\
\hline UFUI & 19.9 & 57.1 & 168 \\
\hline SE $\mathbf{m} \pm$ & 1.16 & 2.83 & 5.31 \\
\hline CD $\mathbf{5} \%$ & 3.42 & 8.35 & 15.6 \\
\hline CV (\%) & 8.14 & 9.63 & 11.5 \\
\hline
\end{tabular}


Table.2 Effect of microbial consortia as basal application and foliar spray of $G$. diazotropicus at different growth stages on plant biomass of maize

\begin{tabular}{|l|c|c|c|c|c|c|}
\hline \multicolumn{1}{|c|}{ Treatments } & \multicolumn{2}{|c|}{ Fresh wt. (mg/ plant) } & \multicolumn{3}{|c|}{ Dry wt. (mg/ } \\
plant)
\end{tabular}


Table.3 Effect of microbial consortia as basal application and foliar spray of G. diazotropicus on total chlorophyll content at different stages of crop growth

\begin{tabular}{|c|c|c|c|}
\hline \multirow[t]{2}{*}{ Treatment } & \multicolumn{3}{|c|}{$\begin{array}{l}\text { Total chlorophyll content } \\
\left.\text { (mg g }{ }^{-1} \text { leaf }\right)\end{array}$} \\
\hline & 35 DAS & 55DAS & 75DAS \\
\hline G. diazotropicus & 1.39 & 1.33 & 1.37 \\
\hline F+G. diazotropicus & 1.60 & 1.65 & 1.64 \\
\hline $\mathbf{F}+$ Arthro & 1.23 & 1.37 & 1.25 \\
\hline F+PSB & 1.46 & 1.55 & 1.43 \\
\hline F+KSB & 1.24 & 1.32 & 1.65 \\
\hline $\mathrm{F}+G$. diazotropicus + Arthro & 1.57 & 1.75 & 1.71 \\
\hline F+G. diazotropicus + PSB & 1.70 & 1.74 & 1.70 \\
\hline F+G. diazotropicus $+\mathrm{KSB}$ & 1.62 & 1.73 & 1.75 \\
\hline F + Arthro + PSB & 1.67 & 1.68 & 1.71 \\
\hline F+Arthro+KSB & 1.56 & 1.66 & 1.69 \\
\hline F+PSB + KSB & 1.56 & 1.70 & 1.62 \\
\hline F+G. diazotropicus + Arthro + PSB & 1.80 & 1.85 & 1.82 \\
\hline $\mathrm{F}+G$. diazotropicus + Arthro $+K S B$ & 1.73 & 1.80 & 1.77 \\
\hline F+G. diazotropicus + PSB + KSB & 1.79 & 1.84 & 1.78 \\
\hline $\mathrm{F}+$ Arthro + PSB + KSB & 1.88 & 1.91 & 1.87 \\
\hline F+G. diazotropicus + Arthro + PSB + KSB & 1.96 & 1.99 & 1.90 \\
\hline FUI & 1.31 & 1.34 & 1.63 \\
\hline UFUI & 1.01 & 1.19 & 1.27 \\
\hline $\mathbf{S E}_{\mathbf{m}} \pm$ & 0.18 & 0.15 & 0.07 \\
\hline $\mathrm{CD}_{5 \%}$ & 0.53 & 0.44 & 0.20 \\
\hline CV $(\%)$ & 7.03 & 8.45 & 10.1 \\
\hline
\end{tabular}


Table.4 Effect of microbial consortia as basal application and foliar spray of $G$. diazotropicus at $4^{\text {th }}$ and $6^{\text {th }}$ DAS on germination of maize

\begin{tabular}{|c|c|c|}
\hline \multirow[t]{2}{*}{ Treatments } & \multicolumn{2}{|c|}{ Germination (\%) } \\
\hline & $4^{\text {th }}$ DAS & $6^{\text {th }}$ DAS \\
\hline G. diazotropicus & 43.3 & 58.7 \\
\hline $\mathrm{F}+G$. diazotropicus & 49.3 & 69.0 \\
\hline $\mathbf{F}+$ Arthro & 52.3 & 70.3 \\
\hline F+PSB & 49.3 & 69.0 \\
\hline $\mathbf{F}+\mathrm{KSB}$ & 46.7 & 70.3 \\
\hline $\mathrm{F}+G$. diazotropicus + Arthro & 44.3 & 69.3 \\
\hline F+G. diazotropicus + PSB & 47.0 & 70.0 \\
\hline $\mathrm{F}+G$. diazotropicus $+\mathrm{KSB}$ & 51.3 & 69.0 \\
\hline F + Arthro + PSB & 50.7 & 67.0 \\
\hline F+Arthro+KSB & 53.7 & 70.0 \\
\hline $\mathbf{F}+\mathrm{PSB}+\mathrm{KSB}$ & 51.3 & 68.0 \\
\hline F+G. diazotropicus + Arthro + PSB & 49.0 & 69.0 \\
\hline $\mathrm{F}+G$. diazotropicus + Arthro + KSB & 49.7 & 70.3 \\
\hline $\mathrm{F}+G$. diazotropicus + PSB + KSB & 49.3 & 71.0 \\
\hline $\mathbf{F}+$ Arthro + PSB + KSB & 49.7 & 71.0 \\
\hline $\begin{array}{l}\text { F+G. diazotropicus }+ \text { Arthro + PSB + } \\
\text { KSB }\end{array}$ & 51.0 & 72.6 \\
\hline FUI & 45.0 & 61.3 \\
\hline UFUI & 39.0 & 56.3 \\
\hline $\mathrm{SE}_{\mathbf{m}} \pm$ & 1.78 & 1.84 \\
\hline $\mathrm{CD}_{5 \%}$ & 5.25 & 5.42 \\
\hline CV (\%) & 5.25 & 5.42 \\
\hline
\end{tabular}


Table.5 Effect of microbial consortia as basal application and foliar spray of G. diazotropicus on grain yield, NPK content and their uptake by grain

\begin{tabular}{|c|c|c|c|c|c|c|c|}
\hline \multirow[t]{2}{*}{ Treatment } & \multirow{2}{*}{$\begin{array}{c}\text { Grain } \\
\text { yield } \\
\left(\mathrm{kg} \mathrm{ha}^{-1}\right)\end{array}$} & \multicolumn{3}{|c|}{$\begin{array}{l}\text { Nutrient content } \\
\qquad(\%)\end{array}$} & \multicolumn{3}{|c|}{$\begin{array}{l}\text { Grain nutrient } \\
\text { uptake }\left(\mathrm{kg} \mathrm{ha}^{-1}\right)\end{array}$} \\
\hline & & $\mathbf{N}$ & $\mathbf{P}$ & $\mathbf{K}$ & $\mathbf{N}$ & $\mathbf{P}$ & $\mathbf{K}$ \\
\hline G. diazotropicus & 1447 & 1.21 & 0.33 & 0.57 & 17.5 & 4.73 & 8.24 \\
\hline $\mathrm{F}+$ G. diazotropicus & 2293 & 1.28 & 0.34 & 0.59 & 29.4 & 7.81 & 13.4 \\
\hline $\mathbf{F}+$ Arthro & 2483 & 1.33 & 0.38 & 0.58 & 33.0 & 9.53 & 14.4 \\
\hline F+PSB & 2281 & 1.33 & 0.36 & 0.58 & 30.4 & 8.22 & 13.1 \\
\hline $\mathbf{F}+\mathrm{KSB}$ & 2296 & 1.27 & 0.34 & 0.62 & 29.1 & 7.91 & 14.1 \\
\hline F+G. diazotropicus + Arthro & 2639 & 1.29 & 0.34 & 0.60 & 34.1 & 8.85 & 15.8 \\
\hline $\mathrm{F}+G$. diazotropicus + PSB & 2762 & 1.34 & 0.33 & 0.60 & 37.1 & 9.15 & 16.6 \\
\hline F+G. diazotropicus $+\mathrm{KSB}$ & 2538 & 1.32 & 0.36 & 0.63 & 33.4 & 9.18 & 15.9 \\
\hline $\mathbf{F}+$ Arthro + PSB & 2749 & 1.35 & 0.34 & 0.63 & 37.0 & 9.42 & 17.4 \\
\hline $\mathrm{F}+$ Arthro+KSB & 2366 & 1.37 & 0.35 & 0.63 & 32.3 & 8.19 & 14.9 \\
\hline F+PSB + KSB & 2265 & 1.35 & 0.35 & 0.64 & 30.6 & 7.93 & 14.4 \\
\hline F+G. diazotropicus + Arthro + PSB & 2794 & 1.36 & 0.35 & 0.66 & 38.1 & 9.87 & 18.5 \\
\hline $\mathrm{F}+G$. diazotropicus + Arthro $+K S B$ & 2754 & 1.39 & 0.36 & 0.67 & 38.3 & 9.82 & 18.3 \\
\hline $\mathrm{F}+G$. diazotropicus + PSB + KSB & 2655 & 1.38 & 0.38 & 0.68 & 36.5 & 10.2 & 18.1 \\
\hline F + Arthro + PSB + KSB & 2611 & 1.40 & 0.37 & 0.66 & 36.4 & 9.66 & 17.1 \\
\hline $\begin{array}{l}\text { F+G. diazotropicus }+ \text { Arthro }+ \text { PSB }+ \\
\text { KSB }\end{array}$ & 2863 & 1.41 & 0.39 & 0.69 & 40.3 & 11.3 & 19.7 \\
\hline FUI & 2146 & 1.20 & 0.34 & 0.58 & 25.7 & 7.20 & 12.4 \\
\hline UFUI & 1348 & 1.16 & 0.32 & 0.56 & 15.6 & 4.25 & 7.5 \\
\hline $\mathrm{SE}_{\mathbf{m}} \pm$ & 2404 & 1.32 & 0.35 & 0.62 & 31.9 & 8.50 & 15.1 \\
\hline $\mathrm{CD}_{5 \%}$ & 42.8 & 0.07 & 0.02 & 0.02 & 1.12 & 0.90 & 0.78 \\
\hline CV (\%) & 126.1 & 0.21 & 0.06 & 0.06 & 3.30 & 2.65 & 2.30 \\
\hline
\end{tabular}


Table.6 Effect of microbial consortia as basal application and foliar spray of G. diazotropicus on stover yield NPK content and their uptake by stover

\begin{tabular}{|c|c|c|c|c|c|c|c|}
\hline \multirow[t]{2}{*}{ Treatment } & \multirow{2}{*}{$\begin{array}{c}\text { Stover } \\
\text { yield } \\
\left(\mathrm{kg} \mathrm{ha}^{-1}\right)\end{array}$} & \multicolumn{3}{|c|}{ Nutrient content $(\%)$} & \multicolumn{3}{|c|}{$\begin{array}{l}\text { Stover uptake of } \\
\text { nutrient }\left(\mathrm{kg} \mathrm{ha}^{-1}\right)\end{array}$} \\
\hline & & $\mathbf{N}$ & $\mathbf{P}$ & $\mathbf{K}$ & $\mathbf{N}$ & $\mathbf{P}$ & $\mathbf{K}$ \\
\hline G. diazotropicus & 6010 & 0.97 & 0.24 & 0.78 & 58.5 & 14.6 & 46.8 \\
\hline F+G. diazotropicus & 9827 & 1.01 & 0.25 & 0.85 & 99.6 & 24.9 & 83.2 \\
\hline F+Arthro & 9981 & 1.01 & 0.26 & 0.83 & 101.1 & 26.2 & 82.5 \\
\hline F+PSB & 8860 & 1.00 & 0.25 & 0.84 & 88.9 & 21.8 & 74.1 \\
\hline $\mathbf{F}+\mathrm{KSB}$ & 8737 & 1.02 & 0.24 & 0.86 & 89.1 & 20.9 & 74.8 \\
\hline F+ G. diazotropicus + Arthro & 8667 & 1.00 & 0.25 & 0.84 & 86.7 & 21.3 & 72.8 \\
\hline F+ G. diazotropicus +PSB & 8846 & 1.01 & 0.26 & 0.82 & 89.6 & 22.7 & 72.8 \\
\hline F+ G. diazotropicus +KSB & 8755 & 1.01 & 0.25 & 0.85 & 88.4 & 21.5 & 74.4 \\
\hline F + Arthro + PSB & 9857 & 1.00 & 0.25 & 0.86 & 98.9 & 24.3 & 84.7 \\
\hline $\mathrm{F}+$ Arthro+KSB & 8933 & 1.01 & 0.25 & 0.86 & 90.5 & 22.0 & 76.8 \\
\hline $\mathbf{F}+\mathbf{P S B}+\mathrm{KSB}$ & 8754 & 1.02 & 0.26 & 0.87 & 89.3 & 23.0 & 75.8 \\
\hline F+ G. diazotropicus + Arthro+PSB & 10619 & 1.01 & 0.27 & 0.91 & 107 & 28.3 & 96.2 \\
\hline $\mathrm{F}+$ G. diazotropicus + Arthro $+\mathrm{KSB}$ & 10280 & 1.03 & 0.26 & 0.90 & 106 & 26.7 & 92.5 \\
\hline $\mathrm{F}+$ G. diazotropicus +PSB + KSB & 9942 & 1.02 & 0.28 & 0.88 & 101 & 27.5 & 87.1 \\
\hline $\mathbf{F}+$ Arthro + PSB + KSB & 10493 & 1.04 & 0.27 & 0.89 & 109 & 28.3 & 93.0 \\
\hline $\begin{array}{l}\text { F+G. diazotropicus + Arthro + PSB } \\
+ \text { KSB }\end{array}$ & 10729 & 1.05 & 0.29 & 0.92 & 112 & 30.7 & 98.3 \\
\hline FUI & 6029 & 0.92 & 0.24 & 0.83 & 55.5 & 14.2 & 50.2 \\
\hline UFUI & 5618 & 0.90 & 0.23 & 0.81 & 50.6 & 12.7 & 45.6 \\
\hline $\mathbf{S E}_{\mathbf{m}} \pm$ & 8940 & 1.00 & 0.25 & 0.85 & 90.2 & 22.9 & 76.7 \\
\hline $\mathbf{C D}_{5 \%}$ & 143.9 & 0.02 & 0.04 & 0.03 & 0.95 & 1.21 & 1.02 \\
\hline CV (\%) & 424.1 & 0.05 & 0.13 & 0.09 & 2.78 & 3.58 & 2.99 \\
\hline
\end{tabular}

Data on stover yield ranged from 10729 to $5618 \mathrm{~kg} \mathrm{ha}{ }^{-1}$. Among all the treatment combinations, $\mathrm{F}+G$. diazotropicus + Arthro $+\mathrm{PSB}+\mathrm{KSB}$ responded the best by $77.9 \%$, followed by, $\mathrm{F}+G$. diazotropicus+ Arthro $+\mathrm{PSB}, \mathrm{F}+$ Arthro $+\mathrm{PSB}+\mathrm{KSB}$ and $\mathrm{F}+G$. diazotropicus + Arthro $+\mathrm{KSB}$ by $76.0,74.7$ and $70.5 \%$, respectively over the control $(6029 \mathrm{~kg}$ $\left.\mathrm{ha}^{-1}\right)$. Arangarasan et al., (1998) studied rice inoculated with diazotrophic bacteria viz.,Azospirillum lipoferum, Herbaspirillum seropedicae and PSB Bacillus megaterium. In inoculated treatments with the two bacterial cultures, increase in shoot and root length, 1000 grain weight and grain yield were recorded over uninoculated control.

\section{References}

Anonymous, 2016. Agriculture statistics at a glance. Agricultural Statistics Division. Director of Economics and Statistics. Deptt. of Agriculture and Cooperation, ministry of Agriculture, Govt. of India, New Delhi.

Arangarasan V, Palaniappan SP and Chelliah S.1998. Inoculation effects of diazotrophs and phosphobacteria on rice. Indian J. Microbiol.38.2: 111-112.

Awasthi R, Tiwari R and Nayyar H. 2011. Synergy between plant and phosphorous solubilizing microbes in soils: 60 Effects on Growth and Physiology of 
crops. International Research Journal of Microbiology (IRJM) (ISSN ) 2.12: 484-503.

Bastian F, Rapparini F, Baraldi R, Piccoli P, Bottini R. 1998. Inoculation with Acetobacter diazotrophicus increases glucose and fructose content in shoots of sorghum. Symbiosis.27.2: 147-156.

Bhargava, BS and Raghupathi HB. 1984. Analysis of plant materials for macro and micronutrients. pp. 49-82.

Bhowmik SN. 1995. Studies on investigation of Acetobacter diazotrophicus strains. M.Sc (Agri) thesis submitted to M.P.K.V., Rahuri MS, India.

Jain PC, Kushwaha PS, Dhakad US, Khan H, Trivedi SK. 1999. Response of chickpea (Cicer arientinum) to phosphorus and biofertilizer. Legume Res.22: 241-244.

Jambukar GS. 2003. Studies on diazotrophs in Beet root (Beta vulgaris L.). M.Sc. (Agri.) Thesis, M.P.K.V., Rahuri (M.S.), India.

Madhaiyan M, Poonguzhali S, Senthilkumar M, Seshadri S, Chung H, Yang J, Sundaram SP and Tongmin SA. 2004, Growth promotion and induction of systemic resistance in rice cultivar Co-
47 (Oryza sativa L.) by Methylobacterium spp. Bot. Bull. Acad. Sin., 45 : 315-325. .

Saravanan VS, Osborne J, Madhaiyan M, Mathew L, Chung J, Ahn K and Sa T. 2007. Zinc metal solubilization by Gluconacetobacter diazotrophicus and induction of pleomorphic cells, Journal of Microbiology and Biotechnology 55(1): 1477-1482.

Sevilla M, Burris RH, Gunapala N, and Kennedy C. 2001. Comparison of benefit to sugarcane plant growth and ${ }^{15} \mathrm{~N}_{2}$ incorporation following inoculation of sterile plants with Acetobacter diazotrophicus wildtype and nif mutant strains. Mol. PlantMicrobe Interact. 14: 359-366.

Sparks DL, Huang PM. 1985. Physical chemistry of soil potassium. Potassium in agriculture, pp. 201-276.

Triplett Eric W. 1996. Diazotrophic endophytes :progress and prospects for nitrogen fixation in monocots. Plant and Soil. 186: 1, 29-38.

Vessey KJ. 2003, Plant growth promotion rhizobacteria as biofertilizer. Plant Soil., 25 : 557-586.

\section{How to cite this article:}

Garima Padwar, N. G. Mitra, Tikam Chand Yadav, R. K. Sahu and Gaurav Padwar. 2020. Effect of Microbial Consortia as Basal Application and Foliar Spray of Gluconacetobacter diazotropicus on Growth, Yield and Nutrient Uptake by Maize. Int.J.Curr.Microbiol.App.Sci. 9(06): 2900-2912. doi: https://doi.org/10.20546/ijcmas.2020.906.350 